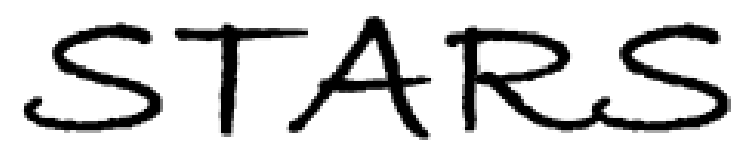

University of Central Florida

STARS

\title{
The complete nucleotide sequence of the coffee (Coffea arabica L.) chloroplast genome: organization and implications for biotechnology and phylogenetic relationships amongst angiosperms
}

Nalapalli Samson

University of Central Florida

Michael G. Bausher

Seung-Bum Lee

University of Central Florida

Robert K. Jansen

Find similar works at: https://stars.library.ucf.edu/facultybib2000 Henry Daniell University of Centralral,Florida Libraries http://library.ucf.edu

This Article is brought to you for free and open access by the Faculty Bibliography at STARS. It has been accepted for inclusion in Faculty Bibliography 2000s by an authorized administrator of STARS. For more information, please contact STARS@ucf.edu.

\section{Recommended Citation}

Samson, Nalapalli; Bausher, Michael G.; Lee, Seung-Bum; Jansen, Robert K.; and Daniell, Henry, "The complete nucleotide sequence of the coffee (Coffea arabica L.) chloroplast genome: organization and implications for biotechnology and phylogenetic relationships amongst angiosperms" (2007). Faculty Bibliography 2000s. 7609.

https://stars.library.ucf.edu/facultybib2000/7609

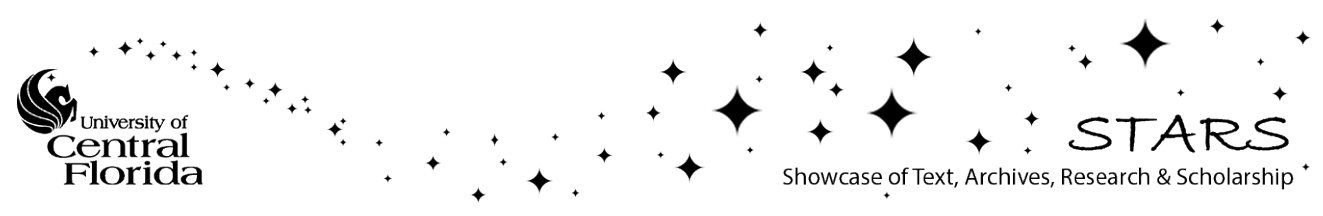




\title{
The complete nucleotide sequence of the coffee (Coffea arabica L.) chloroplast genome: organization and implications for biotechnology and phylogenetic relationships amongst angiosperms
}

\author{
Nalapalli Samson'1, Michael G. Bausher², Seung-Bum Lee ${ }^{1}$, Robert K. Jansen ${ }^{3}$ and Henry Daniell ${ }^{1, *}$ \\ 'University of Central Florida, Department of Molecular Biology and Microbiology, Biomolecular Science, Building \#20, Orlando, FL 32816-2364, USA \\ 2 USDA-ARS, Horticultural Research Laboratory, Fort Pierce, FL 34945-3030, USA \\ ${ }^{3}$ Section of Integrative Biology and Institute of Cellular and Molecular Biology, Patterson Laboratories 141, University of Texas, Austin, TX 78712, USA
}

Received 25 September 2006; revised 21 December 2006; accepted 23 December 2006.

*Correspondence (fax 407-823-0956;

e-mail daniell@mail.ucf.edu)

Keywords: chloroplast genetic engineering, chloroplast genome, coffee, phylogeny, Rubiaceae.

\begin{abstract}
Summary
The chloroplast genome sequence of Coffea arabica L., the first sequenced member of the fourth largest family of angiosperms, Rubiaceae, is reported. The genome is $155189 \mathrm{bp}$ in length, including a pair of inverted repeats of $25943 \mathrm{bp}$. Of the 130 genes present, 112 are distinct and 18 are duplicated in the inverted repeat. The coding region comprises 79 protein genes, 29 transfer RNA genes, four ribosomal RNA genes and 18 genes containing introns (three with three exons). Repeat analysis revealed five direct and three inverted repeats of 30 bp or longer with a sequence identity of $90 \%$ or more. Comparisons of the coffee chloroplast genome with sequenced genomes of the closely related family Solanaceae indicated that coffee has a portion of rps19 duplicated in the inverted repeat and an intact copy of infA. Furthermore, whole-genome comparisons identified large indels (> $500 \mathrm{bp}$ ) in several intergenic spacer regions and introns in the Solanaceae, including trnE (UUC)-trnT (GGU) spacer, ycf4-cemA spacer, trnl (GAU) intron and rrn5-trnR (ACG) spacer. Phylogenetic analyses based on the DNA sequences of 61 protein-coding genes for 35 taxa, performed using both maximum parsimony and maximum likelihood methods, strongly supported the monophyly of several major clades of angiosperms, including monocots, eudicots, rosids, asterids, eurosids II, and euasterids I and II. Coffea (Rubiaceae, Gentianales) is only the second order sampled from the euasterid I clade. The availability of the complete chloroplast genome of coffee provides regulatory and intergenic spacer sequences for utilization in chloroplast genetic engineering to improve this important crop.
\end{abstract}

\section{Introduction}

Coffee is one of the most economically important crops in the world. Approximately 2.25 billion cups of coffee are consumed in the world on a daily basis. In many years, this crop is second in value only to oil as a source of foreign exchange to several developing countries. Worldwide, an estimated 15 billion coffee trees are grown on $100000 \mathrm{~km}^{2}$ of land. Coffee is a member of Rubiaceae, the fourth largest family of angiosperms (Stevens, 2006). Most coffee beans come from two species of Coffea. Coffea arabica is considered to have the best quality and aroma, but this species is highly susceptible to several pathogens, including the fungus Fusarium oxysporum, nematodes (mainly Meloidogyne sp. and Pratylenchus spp.), coffee rust (Hemileia vastatrix), coffee stem borers (beetles in the family Cerambycidae) and coffee berry borer (Hypothenemus hampei). Coffea canephora is resistant to most of these pests, but the quality of the beans is poor. There is a need to improve the resistance of $C$. arabica to pests, which cause severe damage to coffee trees and substantial tree mortality in Africa, Asia and Latin America (USDA, 2005). 
During the past 15 years, different research groups have successfully performed the genetic transformation of coffee. The earlier reports on coffee genetic transformation in the 1990s showed co-cultivation of C. arabica protoplasts with different strains of Agrobacterium tumefaciens using neomycin phosphotransferase type II gene (NPT II) selection and $\beta$ glucuronidase (GUS) marker genes (Spiral and Pétiard, 1991). Barton et al. (1991) obtained transformed somatic embryos of $C$. arabica by the electroporation method to integrate foreign genes. Van Boxtel et al. (1995) showed transient GUS expression in C. arabica using the biolistic method. Ocampo and Manzanera (1991) demonstrated that C. arabica tissue could be infected by wild strains of $A$. tumefaciens. Van Boxtel et al. (1997) evaluated the effectiveness of five selective agents (chlorsulphuron, glufosinate, glyphosate, hygromycin and kanamycin) for the selection of transformed embryogenic cell lines. Because of public and consumer concerns about the use of antibiotic-resistant marker genes in transformed plants, Penna et al. (2002) proposed several positive selection systems as alternative methods.

Despite considerable advances in coffee genetic transformation, the ability to introduce useful traits, such as insect resistance, did not occur until the turn of the century, when Leroy et al. (2000) expressed synthetic Cry1Ac to enhance leaf miner resistance. Ogita et al. (2003) obtained transgenic coffee plants with suppressed caffeine synthesis using RNA interference (RNAi) technology. They successfully produced low-caffeine plantlets of $C$. canephora through the downregulation of CaMXMT1 (theobromine synthase) and CaDXMT1 (caffeine synthase), achieving $70 \%$ reduction of both theobromine and caffeine in the leaves compared with control plants. Another desirable trait of coffee quality is uniformity in fruit ripening, which has a major impact on the quality of coffee (Ribas et al., 2006). ACC oxidase (Ca ACO) genes promote uniform fruit ripening (Pereira et al., 2005). During the maturation of fruits, there is a dramatic increase in ethylene biosynthesis that promotes subsequent steps of fruit ripening with biochemical and physiological changes. Recently, the ACC oxidase gene involved in ethylene production has been cloned and characterized (Pereira et al., 2005). These genes are potential candidates for coffee transformation.

Crop improvement via interspecific and/or intraspecific breeding programmes is very time consuming because coffee is a perennial plant, and these programmes are impeded by the slow flowering time of 3-6 years. Because several backcrosses are needed to select for desirable traits, it takes a considerable time to develop disease-resistant trees. Despite the numerous backcrosses performed, unwanted chromosomal regions often remain in the offspring of interspecific crosses, reducing their survival. An alternative approach for developing disease-resistant coffee plants may be chloroplast genetic engineering (Daniell et al., 2004a,b, 2005; Grevich and Daniell, 2005). The presence of numerous copies of the plastid genome within chloroplasts favours a high level of expression of introduced foreign genes. MendezLopez et al. (2003) recently demonstrated that a Bt toxin from Bacillus thuringiensis serovar israelensis is highly toxic to the first year instar of coffee berry borer larvae. They found that a paraporal crystal of $B$. thuringiensis serovar israelensis is lethal to the larvae at $219.5 \mathrm{ng} / \mathrm{cm}^{2}$. Expression of this protein in the chloroplast should provide a very high level of toxicity to insects (Kota et al., 1999; DeCosa et al., 2001). The expression of antimicrobial peptides, MSI-99, via the chloroplast genome produced disease resistance of up to $88 \%-$ 96\% against bacterial (Pseudomonas syringae) and fungal (Aspergillus flavus, Fusarium moniliforme and Verticillium) pathogens (DeGray et al., 2001). Multigene engineering in a single transformation event (Ruiz et al., 2003; QuesadaVargas et al., 2005), transgene containment via maternal inheritance (Daniell et al., 1998; Scott and Wilkinson, 1999; Daniell, 2002) or cytoplasmic male sterility (Ruiz and Daniell, 2005), lack of gene silencing (DeCosa et al., 2001), elimination of position effect by site-specific transgene integration (Daniell et al., 2002) and pleiotropic effects by subcellular compartmentalization of transgene products (Daniell et al., 2001; Lee et al., 2003; Leelavathi et al., 2003) are other advantages offered by chloroplast genetic engineering.

Plastid genetic engineering should open up the possibility of enhancing the quality of coffee by the over-expression of enzymes, such as methionine synthase/cysteine synthase involved in methionine/cysteine production; increased levels of these amino acids in coffee are known to improve flavour (Carneiro, 1997). Naturally decaffeinated coffee will be of great interest to consumers who are concerned about the adverse health effects of caffeine intake. $N$-Methyltransferase (caffeine synthase) is a chloroplast enzyme that catalyses the last two steps in caffeine production through the conversion of 7-methylxanthine to theobromine and theobromine to caffeine (Ashihara and Crozier, 2001). Over-expression of the $\mathrm{N}$-7-demethylase gene from Coffea eugenioides within plastids of transformed coffee plants is likely to produce plants with low caffeine content, as the $C$. eugenioides gene product will catalyse the metabolism of caffeine to theophylline, which is catabolized to $\mathrm{CO}_{2}$ and $\mathrm{NH}_{3}$ through the purine catabolic pathway.

To date, engineering of the chloroplast genome has been extended to only a few important crops, including carrot (Kumar et al., 2004a), cotton (Kumar et al., 2004b), lettuce 
Table 1 List of genes encoded by the coffee chloroplast genome

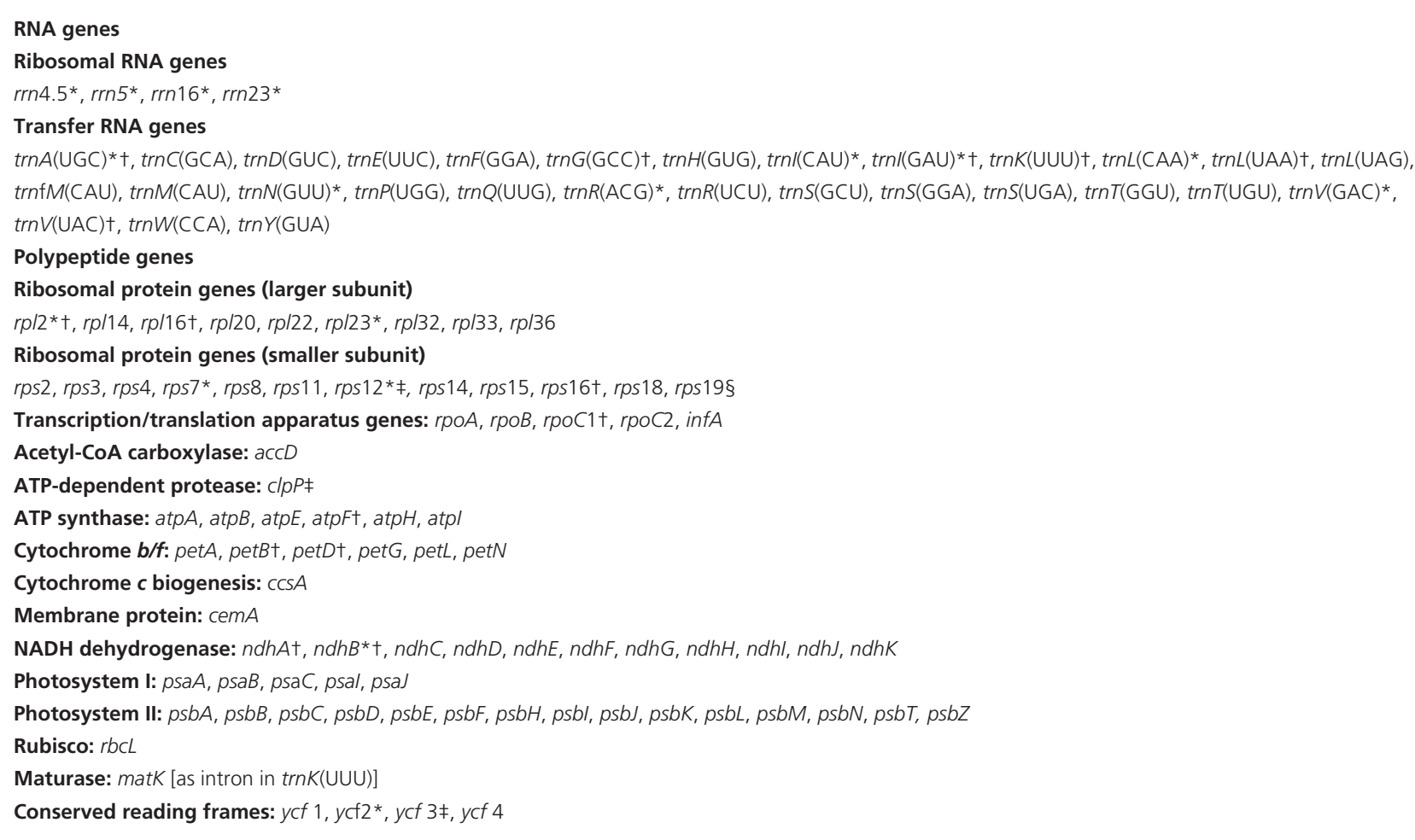

$\mathrm{NADH}$, reduced nicotinamide adenine dinucleotide; Rubisco, ribulose-1,5-bisphosphate carboxylase/oxygenase.

*Gene duplicated in the inverted repeat.

tGene with one intron.

‡Gene with two introns.

$\S$ Gene truncated in IRa.

(Lelivelt et al., 2005; Kanamoto et al., 2006), potato (Sidorov et al., 1999), poplar (Okumura et al., 2006), rice (Lee S.M. et al., 2006), soybean (Dufourmantel et al., 2004, 2005) and tomato (Ruf et al., 2001). In order to achieve reproducible plastid transformation in coffee, a knowledge of the complete plastid genome sequence is essential. This facilitates the identification of appropriate spacer regions for the integration of transgenes at optimal sites via homologous recombination, as well as endogenous regulatory sequences for the optimal expression of transgenes (Maier and Schmitz-Linneweber, 2004; Daniell et al., 2005). These data also provide a rich source of nucleotide sequences for phylogenetic and molecular evolutionary questions (Goremykin et al., 2003, 2004, 2005; Leebens-Mack et al., 2005; Bausher et al., 2006; Chang et al., 2006; Jansen et al., 2006; Lee S.B. et al., 2006; Ruhlman et al., 2006).

In this article, we report the complete sequence of the coffee chloroplast genome. In addition to discussing the biotechnological applications of this new genome sequence, we use these data to compare the genome organization and phylogenetic relationships of coffee to other angiosperms, especially the closely related family Solanaceae.

\section{Results}

\section{Genome organization}

The chloroplast genome of coffee is a circular DNA molecule of 155189 bp with a quadripartite structure typical of the majority of land plant chloroplast chromosomes. It includes two inverted repeat regions (IRa and IRb) of 25943 bp separated by large (LSC) and small (SSC) single-copy regions of 85166 and 18137 bp, respectively (Figure 1). The proportions of protein, transfer RNA (tRNA), ribosomal RNA (rRNA), intron and intergenic sequences are 51\%,2\%,6\%, 9\% and $32 \%$, respectively. Of the 130 genes present in the genome (Table 1), 112 are present as a single copy and 18 are duplicated in the IR. The coding region includes 79 protein genes, 29 tRNAs and four rRNAs. The coffee chloroplast genome has $59.35 \%$ coding sequence, $51.76 \%$ of which codes for proteins. 


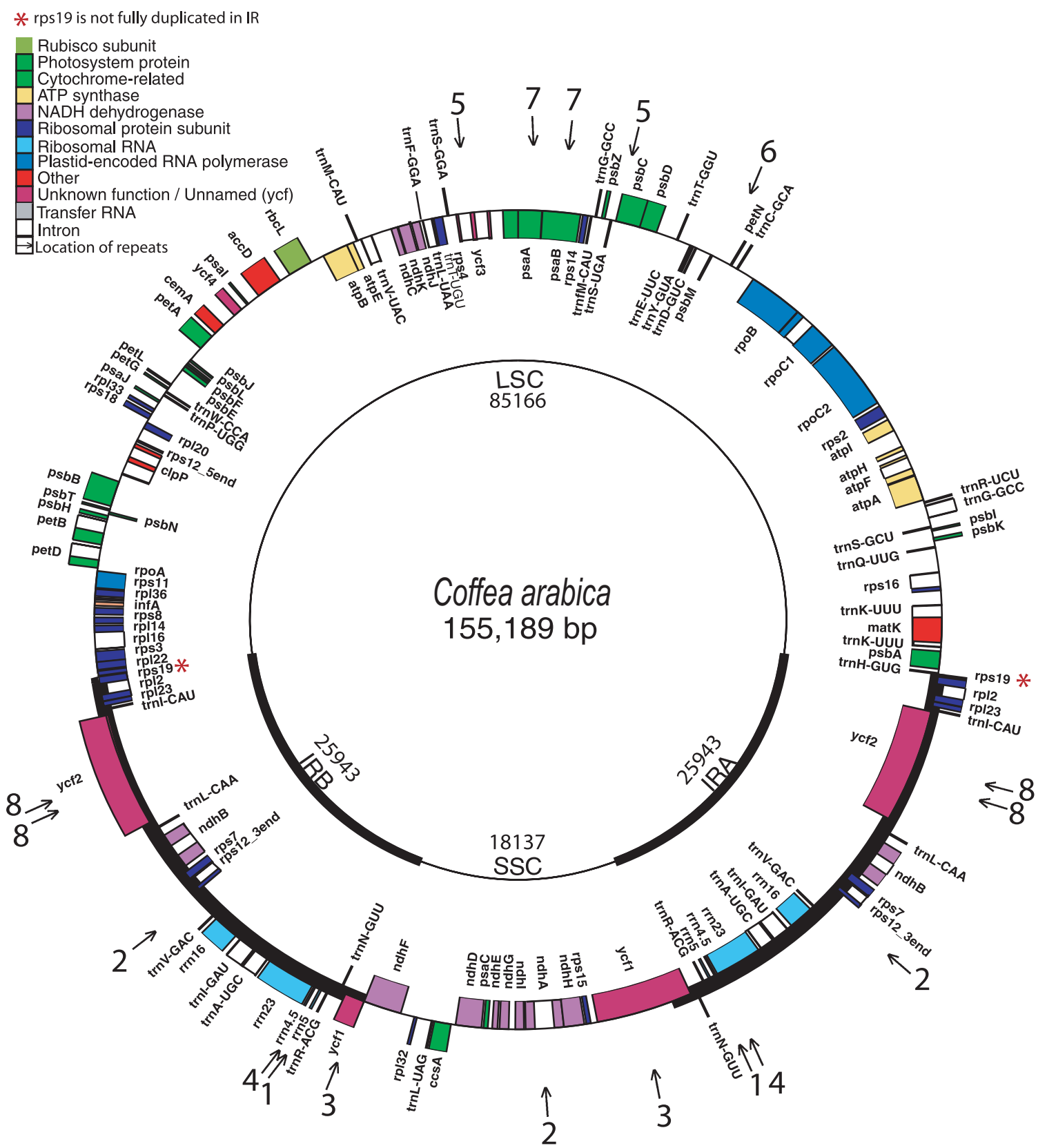

Figure 1 Circular gene map of the Coffea arabica chloroplast genome. The thick lines indicate the extent of the inverted repeats (IRa and IRb, 25943 bp), which separate the genome into small (SSC, 18133 bp) and large (LSC, 85166 bp) single-copy regions. Genes on the outside of the map are transcribed in the clockwise direction and genes on the inside of the map are transcribed in the counterclockwise direction. ${ }^{*}$ The rps 19 gene locates entirely in the IRb region and partly in the IRa region. Arrows show the location of repeats (for more details on repeats, see Table 3).

Eighteen genes contain introns, 15 with two exons and three with three exons. Twelve protein-coding genes and six tRNAs have introns (Table 2). A portion of the rps19 gene is duplicated at the IRa-LSC boundary as a result of expansion of the IR. A similar duplication of portions of rps19 occurs in all members of the related family Solanaceae except tobacco (Chung et al., 2006). In addition, in the case of coffee, we observed that the infA gene is intact, whereas it is a pseudogene in tobacco and in most other members of the Solanaceae. The AT and GC contents of the coffee chloroplast genome are $63 \%$ and $37 \%$, respectively, very similar to those of rice, maize, citrus, cotton and tobacco.

Repeat analysis revealed five direct repeats and three IRs of $30 \mathrm{bp}$ or longer with sequence identity of $90 \%$ or more (Table 3, Figure 1). Three direct repeats and two IRs were located in intergenic spacer (IGS) regions. The remaining 
Table 2 List of genes containing introns in the coffee chloroplast genome

\begin{tabular}{|c|c|c|c|}
\hline Number & Gene name & Intron size (bp) & Type of gene \\
\hline 1 & $\operatorname{trnK-UUU~}$ & $2541 *$ & Transfer RNA \\
\hline 2 & rps16 & 834 & Protein \\
\hline 3 & $\operatorname{trnG-GCC}$ & 693 & Transfer RNA \\
\hline 4 & $\operatorname{atp} F$ & 693 & Protein \\
\hline 5 & rpoC1 & 738 & Protein \\
\hline 6 & $y c f 3 \neq$ & 749,699 & Protein \\
\hline 7 & $\operatorname{trn} L-U A A$ & 494 & Transfer RNA \\
\hline 8 & $\operatorname{trnV} \mathrm{V}-\mathrm{UAC}$ & 594 & Transfer RNA \\
\hline 9 & clpP $\neq$ & 627,776 & Protein \\
\hline 10 & petB & 765 & Protein \\
\hline 11 & petD & 719 & Protein \\
\hline 12 & $r p / 16$ & 1000 & Protein \\
\hline 13 & rpl2† & 659 & Protein \\
\hline 14 & rps12†‡ & 526 & Protein \\
\hline 15 & trnl-GAUt & 936 & Transfer RNA \\
\hline 16 & $\operatorname{trnA-UGC}+$ & 811 & Transfer RNA \\
\hline 17 & $n d h B+$ & 602 & Protein \\
\hline 18 & $n d h A$ & 1117 & Protein \\
\hline
\end{tabular}

*Intron includes 2528 bp of the protein-coding gene matK.

tGene located in inverted repeat (IR).

¥Gene contains two introns.

three repeats (one inverted and two direct) were located in the protein-coding genes psaA, psaB, ycf1 and ycf2. The longest repeat of $64 \mathrm{bp}$ occurred in the intergenic region between $r r n 5$ and $\operatorname{trnR}(\mathrm{ACG}$ ) within the IR (Figure 1). Comparative repeat analysis (CRA) of other representative eudicot crop plants identified eight (C. arabica), 12 (Solanum lycopersicum and Vitis vinifera), 14 (Solanum bulbocastanum), 15 (Daucus carota), 19 (Citrus sinensis), 25 (Gossypium hirsutum) and 39 (Glycine max) repeats.

There are 130 IGS regions ranging from 1 to $1620 \mathrm{bp}$ in the coffee chloroplast genome, representing $31 \%$ of the genome. Eight IGS regions, rps16-trnQ (UUG), atpH-atp I, rpoB-trnC (GCA), petN-petM, trnT (GGU)-psbD, ndhC-trnV (UAC), psbE-petL and rps12-3end-trnV (GAC), are longer than $1000 \mathrm{bp}$, and all are located in the LSC, except for the rps12 and trnv (GAC) region within the IR. Whole-genome sequence comparisons between coffee and four Solanaceae members using the MultiPipMaker program revealed several large (> $500 \mathrm{bp}$ ) deletions (red boxes in Figure 2). Three of these deletions within one IGS region [rps16-trnQ (UUG) and two introns (trnI (GAU) of IRa and IRb)] are present in all members of Solanaceae. A fourth deletion in the IGS region of $\operatorname{trnE}(\mathrm{UUC})-\operatorname{trnT}(\mathrm{GGU})$ is only found in the two Solanum species, and a fifth located in the IGS region of ycf4-cemA is restricted to Nicotiana tabacum.

\section{Phylogenetic relationships}

Our data included 61 protein-coding genes for 35 taxa (Table 4), including 33 angiosperms and two gymnosperm outgroups (Pinus and Ginkgo). The data set comprised 46437 aligned nucleotide positions but, when the gaps were excluded, there were 39936 characters. Gaps were excluded to avoid alignment ambiguities, which were more pronounced for several divergent genes, including $\operatorname{ccS} A$, matK, rpoC2, rps15 and rps18.

Maximum parsimony (MP) analyses resulted in a single, fully resolved tree with a length of 61797 , a consistency index of 0.41 (excluding uninformative characters) and a retention index of 0.58 (Figure 3). Bootstrap analyses indicated that 24 of the 32 nodes were supported by values of $95 \%$ or greater, and 23 of these had a bootstrap value of $100 \%$. Of the remaining eight nodes, five had bootstrap values between $70 \%$ and $95 \%$. Maximum likelihood (ML) analysis resulted in a single tree with $-\ln L=348679.23765$ (Figure 4). ML bootstrap values were also high, with values of $95 \%$ or greater for 28 of the 32 nodes and 21 nodes with

Table 3 Location of repeats in the coffee chloroplast genome. The table includes repeats of at least $30 \mathrm{bp}$ in size, with a sequence identity of $90 \%$ or more (see Figure 1 for location of repeats on the gene map)

\begin{tabular}{llll}
\hline Repeat no. & Repeat length & Repeat & Location \\
\hline 1 & 64 & Direct & IGS (rrn5-trnR-ACG) : IGS (rrn5-trnR-ACG) \\
2 & 41 & Direct & IGS (rps12-trnV-GAC) : intron (ndhA) \\
3 & 34 & Inverted & IGS (ycf1-ndhF) : ycf1 \\
4 & 32 & Direct & IGS (rrn4.5-rrn5) : IGS (rrn4.5-rrn5) \\
5 & 33 & Inverted & IGS (psbC-trnS-UGA) : intron (ycf3) \\
6 & 30 & Inverted & IGS (petN-psbM) : IGS (petN-psbM) \\
7 & 30 & Direct & psaB : psaA \\
8 & 30 & Direct & ycf2 : ycf2 \\
\hline
\end{tabular}

IGS, intergenic spacer. 


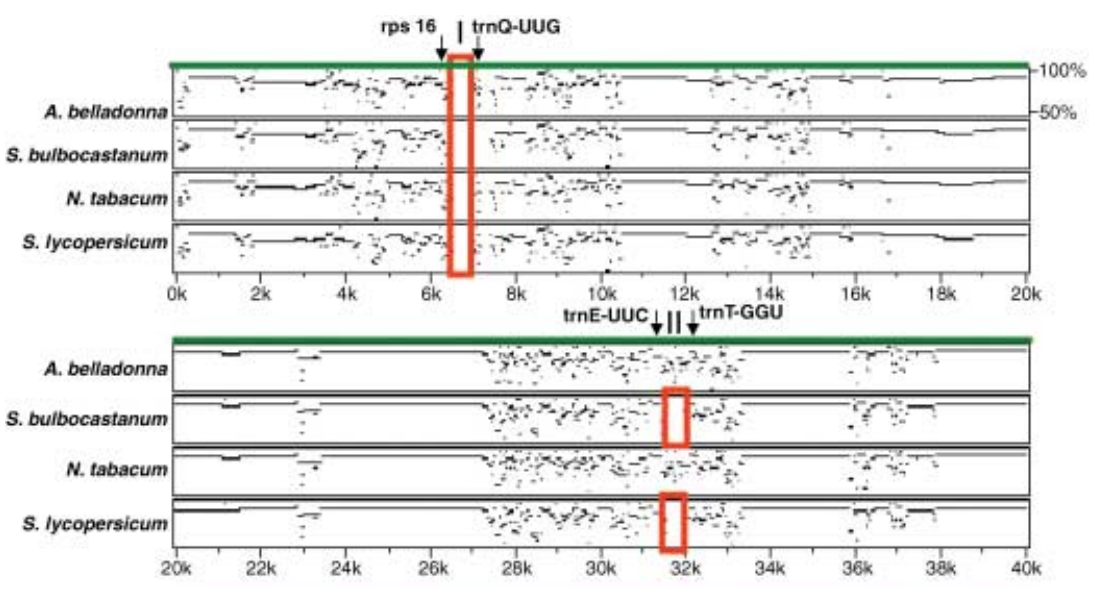

S. bulbocastanum
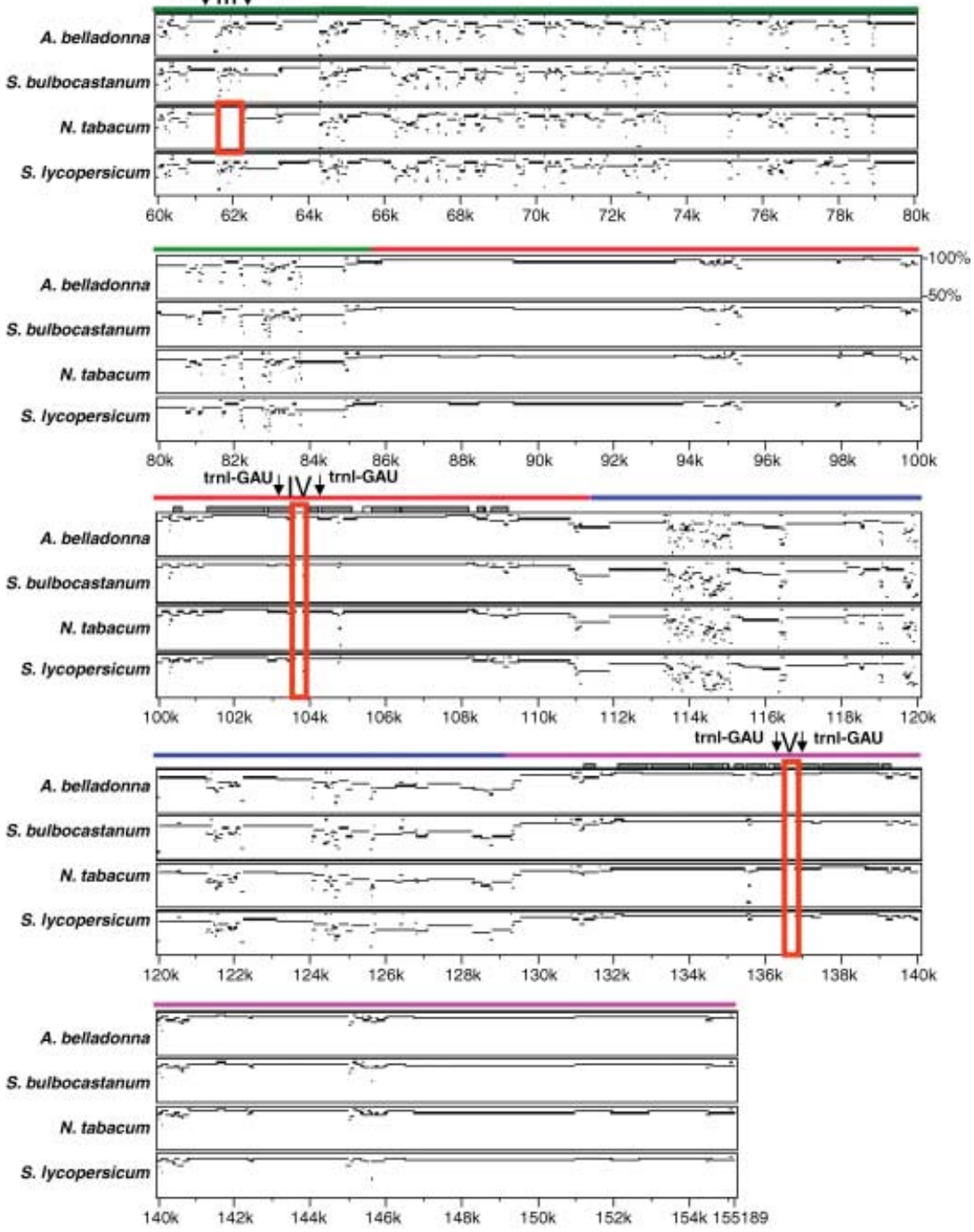

Figure 2 The chloroplast genome comparison derived through a percentage identity plot of coffee against four Solanaceae members (Atropa belladonna, Solanum bulbocastanum, Nicotiana tabacum and Solanum lycopersicum) using the MultiPipMaker alignment tool. DNA losses are marked with roman numerals and the red boxes. I, region within intergenic spacer (IGS) [rps16-trnQ (UUG)]; II, region within IGS [trnE (UUC)-trnl (GGU)]; III, region within IGS (ycf4-cemA); IV, intron [IRb: trnl (GAU)]; $V$, intron [IRa: $\operatorname{trnl}(\mathrm{GAU})]$. 
Table 4 Taxa included in the phylogenetic analyses with GENBANK accession numbers and references

\begin{tabular}{|c|c|c|c|}
\hline & Taxon & GENBANK accession number & Reference \\
\hline \multicolumn{4}{|l|}{ Gymnosperm outgroups } \\
\hline & Pinus thunbergii & NC_001631 & Wakasugi et al. (1994) \\
\hline & Ginkgo biloba & DQ069337-DQ069702 & Leebens-Mack et al. (2005) \\
\hline \multicolumn{4}{|l|}{ Basal angiosperms } \\
\hline & Amborella trichopoda & NC_005086 & Goremykin et al. (2003) \\
\hline & Nuphar advena & DQ069337-DQ069702 & Leebens-Mack et al. (2005) \\
\hline & Nymphaea alba & NC_006050 & Goremykin et al. (2004) \\
\hline \multicolumn{4}{|l|}{ Magnoliids } \\
\hline & Calycanthus floridus & NC_004993 & Goremykin et al. (2003) \\
\hline \multicolumn{4}{|l|}{ Monocots } \\
\hline & Acorus americanus & DQ069337-DQ069702 & Leebens-Mack et al. (2005) \\
\hline & Oryza sativa & NC_001320 & Hiratsuka et al. (1989) \\
\hline & Phalaenopsis aphrodite & NC_007499 & Chang et al. (2006) \\
\hline & Saccharum officinarum & NC_006084 & Asano et al. (2004) \\
\hline & Triticum aestivum & NC_002762 & Ogihara et al. (2002) \\
\hline & Typha latifolia & DQ069337-DQ069702 & Leebens-Mack et al. (2005) \\
\hline & Yucca schidigera & DQ069337-DQ069702 & Leebens-Mack et al. 2005 \\
\hline & Zea mays & NC_001666 & Maier et al. (1995) \\
\hline \multicolumn{4}{|l|}{ Eudicots } \\
\hline & Arabidopsis thaliana & NC_000932 & Sato et al. (1999) \\
\hline & Atropa belladonna & NC_004561 & Schmitz-Linneweber et al. (2001) \\
\hline & Citrus sinensis & NC_008334 & Bausher et al. (2006) \\
\hline & Coffea arabica & NC_008535 & Current study \\
\hline & Cucumis sativus & NC_007144 & Plader, W.W., et al., Warsaw \\
\hline & & & $\begin{array}{l}\text { Agricultural University, unpubl. } \\
\text { data }\end{array}$ \\
\hline & NC_008325 & DQ898156 & Ruhlman et al. (2006) \\
\hline & Eucalyptus globulus & NC_008115 & Steane $(2005)$ \\
\hline & Glycine max & NC_007942 & Saski et al. (2005) \\
\hline & Gossypium hirsutum & NC_007944 & Lee S.M. et al. (2006) \\
\hline & Lactuca sativa & DQ383816 & Timme et al. (2007) \\
\hline & Lotus corniculatus & NC_002694 & Kato et al. (2000) \\
\hline & Medicago truncatula & NC_003119 & $\begin{array}{l}\text { Lin, S. et al., The University of } \\
\text { Oklahoma, unpubl. data }\end{array}$ \\
\hline & Nicotiana tabacum & NC_001879 & Shinozaki et al. (1986) \\
\hline & Oenothera elata & NC_002693 & Hupfer et al. (2000) \\
\hline & Panax schinseng & NC_006290 & Kim \& Lee (2004) \\
\hline & Populus trichocarpa & NC_008235 & Okumura, S. et al., Research \\
\hline & & & $\begin{array}{l}\text { Institute of Innovative Technology } \\
\text { for the Earth, Kyoto, unpubl. data }\end{array}$ \\
\hline & Ranunculus macranthus & DQ069337-DQ069702 & Leebens-Mack et al. (2005) \\
\hline & Solanum lycopersicum & DQ347959 & Daniell et al. (2006) \\
\hline & Solanum bulbocastanum & NC_007943 & Daniell et al. (2006) \\
\hline & Spinacia oleracea & NC_002202 & Schmitz-Linneweber et al. (2001) \\
\hline & Vitis vinifera & NC_007957 & Jansen et al. (2006) \\
\hline
\end{tabular}

100\% bootstrap support. The remaining four nodes had bootstrap values of less than $75 \%$. The ML and MP trees had very similar topologies (compare Figures 3 and 4). Agreement between the two trees included the position of Amborella alone as sister to the remaining angiosperms, the placement of the magnoliid genus Calycanthus sister to eudicots, the sister relationship between Caryophyllales and asterids, and strong support for the monophyly of several major clades, including monocots, eudicots, rosids, eurosids II, asterids, and euasterids I and II. The only incongruence between the MP and ML trees concerned relationships amongst the rosids. Specifically, the position of the clade that included Cucumis and the Myrtales (Eucalyptus and Oenothera) varied in the trees generated by the different 


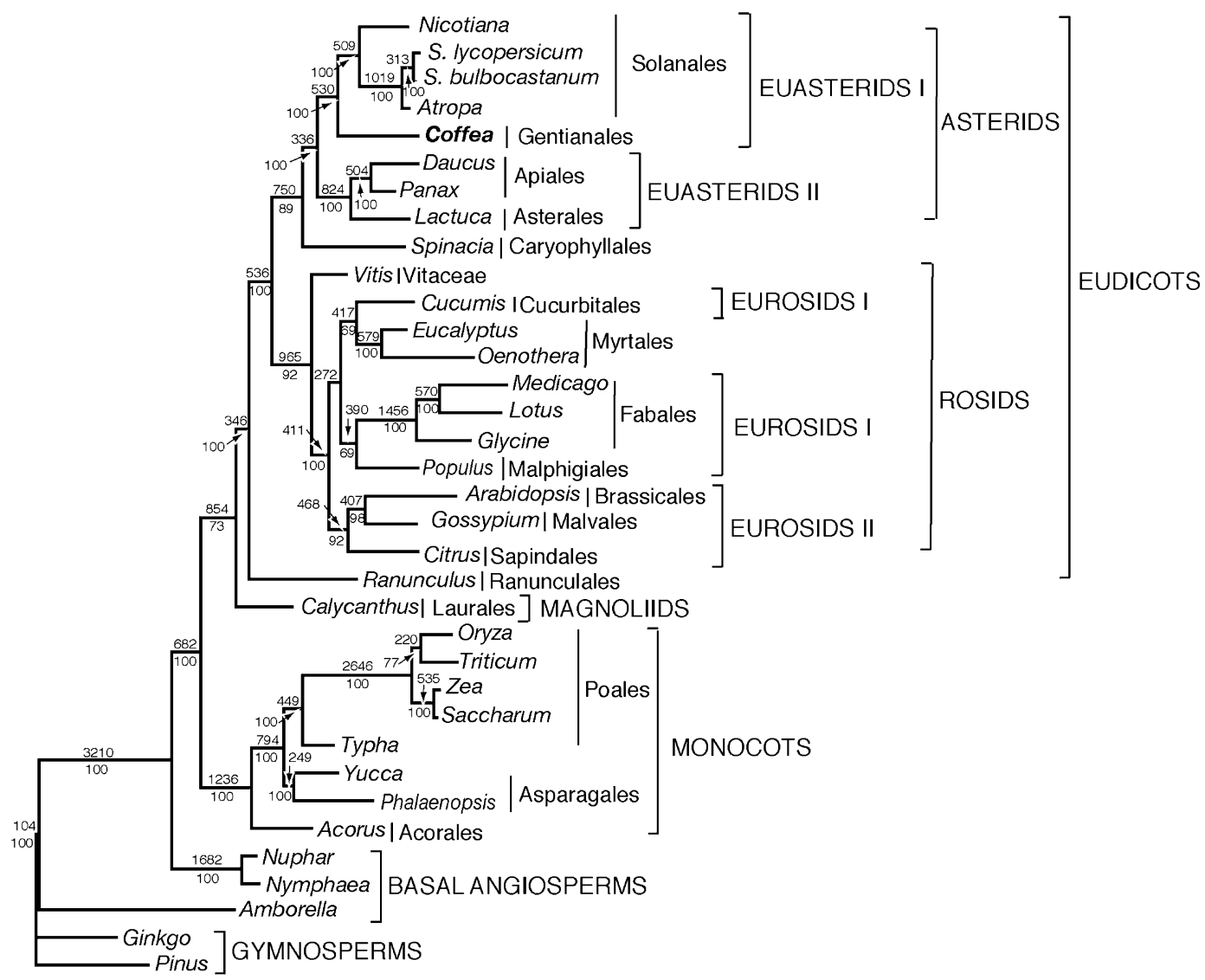

Figure 3 Maximum parsimony tree based on 61 chloroplast protein-coding genes (data are available at http://www.biosci.utexas.edu//B/faculty/jansen/ lab/research/datafiles/index.htm). The single most parsimonious phylogram has a length of 61 797, a consistency index of 0.41 (excluding uninformative characters) and a retention index of 0.58 . Numbers above and below the nodes indicate the number of nucleotide substitutions and bootstrap support values, respectively.

methods, but support for alternative placements was weak. The MP tree (Figure 3) placed the Cucumis-Myrtales clade sister to a clade that includes the eurosid I taxa from the Fabales and Malphigiales. In contrast, the ML tree (Figure 4) placed the Cucumis-Myrtales clade sister to the eurosid II clade. Support for the different relationships of the CucumisMyrtales clade was $<50 \%$ in both MP and ML trees. In both analyses, members of eurosids I were not monophyletic. Both MP and ML trees provided very strong support (100\% bootstrap) for the sister relationship of Coffea (Gentianales) and the Solanales in the euasterid I clade.

\section{Discussion}

\section{Genome organization}

The gene order of the coffee plastid genome is identical to the inferred ancestral angiosperm plastome organization, emphasizing the highly conserved nature of these genomes amongst land plants (Raubeson and Jansen, 2005). Our examina- tion of the occurrence of repeated sequences in the coffee chloroplast genome confirms reports from several recent studies indicating that these genomes contain a number of direct repeats and IRs, even when genomes have not undergone rearrangements, including soybean (Saski et al., 2005), cotton (Lee S.B. et al., 2006), potato and tomato (Daniell et al., 2006), grape (Jansen et al., 2006), citrus (Bausher et al., 2006) and carrot (Ruhlman et al., 2006). In all of the plastid genomes examined so far, repeats are more prevalent in IGSs and introns, with fewer repeats located in the genes ycf2, psaA and $p s a B$. Studies of repeats in highly rearranged genomes (Pombert et al., 2005, 2006; Chumley et al., 2006) have demonstrated a correlation between the number of repeats and the degree of gene order change, and many rearrangement endpoints have associated repeat elements. In these genomes, it is evident that repeated sequences have played a role in changes in gene order and content. The role of repeat elements in genomes that have not experienced rearrangements is unknown.

In the case of C. arabica, we identified fewer repeats (eight) than have been reported in a number of other crop 


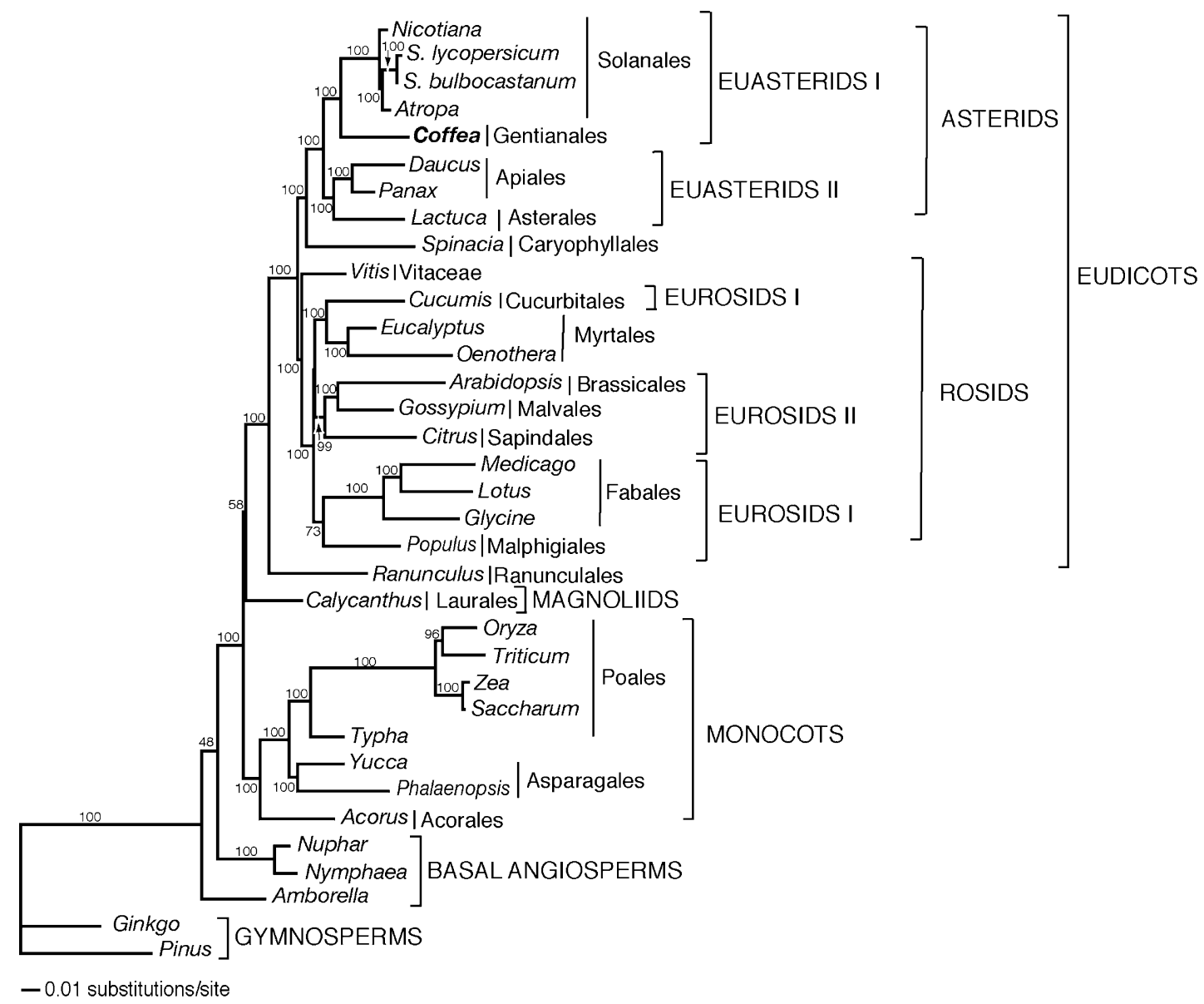

Figure 4 Maximum likelihood tree based on 61 chloroplast protein-coding genes. The single maximum likelihood phylogram has a maximum likelihood value of $-\operatorname{In} L=348679.23765$. Numbers at the nodes indicate the bootstrap support values and the branch length scale is shown at the base of the tree.

Table 5 Repeat analysis of the chloroplast genome of selected crop plants using comparative repeat analysis (CRA). Data include direct, inverted, complement and reverse repeats with a minimum size of $30 \mathrm{bp}$ and a sequence identity of $90 \%$ or more

\begin{tabular}{|c|c|c|c|c|c|}
\hline Crop plant & No. of direct repeats & No. of inverted repeats & No. of complement repeats & No. of reverse repeats & Total number of repeats \\
\hline Coffea arabica & 5 & 3 & - & - & 8 \\
\hline Citrus sinensis & 9 & 6 & 1 & 3 & 19 \\
\hline Daucus carota & 13 & 2 & - & - & 15 \\
\hline Gossypium hirsutum & 16 & 6 & - & 3 & 25 \\
\hline Glycine max & 13 & 17 & 3 & 6 & 39 \\
\hline Solanum lycopersicum & 9 & 1 & - & 2 & 12 \\
\hline Solanum bulbocastanum & 10 & 1 & - & 3 & 14 \\
\hline Vitis vinifera & 8 & 1 & - & 3 & 12 \\
\hline
\end{tabular}

plants, including Daucus carota (14; Ruhlman et al., 2006), Gossypium hirsutum (54; Lee S.B. et al., 2006), Citrus sinensis (29; Bausher et al., 2006), Vitis vinifera (36; Jansen et al., 2006), Glycine max (287; Saski et al., 2005), Solanum bulbocastanum (31; Daniell et al., 2006) and Solanum lycopersicum
(40; Daniell et al., 2006). The reason for this difference is that we used the CRA program instead of REPuter. REPuter uses pair-wise comparisons to identify repeats, and calculates the number of unique pairs, not the actual number of repeats. Thus, a repeat with multiple copies will be recorded multiple 
times. REPuter also over-estimates the number of repeats by recognizing several nested series of repeats within a given region containing multiple repeats. The use of an improved algorithm in the CRA program filters out these repeats and therefore more accurately identifies the number of repeated sequences. The number of repeats revealed by CRA was in the range 8-39, rather than the range 8-287 reported in the published literature. The maximum number of repeats was identified in Glycine max (39), the fewest in C. arabica, and similar numbers of repeats were found in other crop plant chloroplast genomes (Table 5). The most probable explanation for the larger numbers of repeats in the Glycine max genome is that it contains some rearrangements, a common feature of legume genomes. Another possible explanation for the lower number of repeats in C. arabica could be related to A-T richness. It is widely accepted that repeats in chloroplast genomes tend to be A-T rich. Although we did not compare A-T richness in the crop plant genomes, this would be worthwhile in a more comprehensive, comparative study of chloroplast genomes.

Millen et al. (2001) observed that the infA gene, which codes for translation initiation factor 1 , stands out as an unusually unstable angiosperm chloroplast gene, having been lost from the chloroplast genome on many separate occasions and transferred to the nucleus multiple times. In coffee, infA is intact, in contrast with the closely related family Solanaceae, where it is a pseudogene in tobacco and 17 other species examined. Millen et al. (2001) surveyed four genera of Rubiaceae, Coffea, Galium, Ixora and Pentas, using a combination of Southern hybridization with an infA probe and DNA sequencing. Two genera, Coffea and Ixora, had infA, whereas, in the other two genera, Pentas and Galium, the gene was absent in the chloroplast genome. Thus, there is variation within the Rubiaceae with regard to the presence or absence of infA.

For the expression of foreign proteins, genes are targeted into the spacer regions of the chloroplast genome for stable integration. The use of a $100 \%$ identity of the flanking sequence is optimal for stable integration of foreign genes by homologous recombination into the plastid genome. However, spacer regions are not $100 \%$ identical even in members of the same family. Recently, Daniell et al. (2006) examined the similarities between the sequenced chloroplast genomes of Solanaceae, and found that only four spacer regions had $100 \%$ identity amongst the four genomes studied. They also found that, between Solanum lycopersicum and Solanum bulbocastanum, 21 IGS regions had 100\% identity, whereas only eight IGS regions had $100 \%$ sequence identity between Solanum lycopersicum and Atropa belladonna, and Nicotiana tabacum and Solanum bulbocastanum. In addition, several deletions and insertions were found in the IGS regions of trnQ (UUG)-rps16, trnE (UUC)-trnT (GGU), trnK (UUU)rps16, trnS (GCU)-trnG (GCC), ycf2-trnI (CAU), ycf 4-cemA and ycf15-trnL (CAA) amongst the Solanaceae genomes examined. Analysis of the coffee chloroplast genome also identified deletions in the IGS regions of rps16-trnQ (UUG), $\operatorname{trnE}$ (UUC)-trnT (GGU), ycf4-cemA and in the trnl (GAU) intron relative to Atropa belladonna, Solanum bulbocastanum, Nicotiana tabacum and Solanum lycopersicum (Figure 2). A correlation between a low frequency of plastid transformation and the use of flanking sequences of lower sequence identity has been noted (Daniell et al., 2006). This study further highlights the importance of choosing IGS regions that have high sequence identity. Alternatively, species-specific vectors from the appropriate IGS region obtained from the coffee chloroplast genome could be used for successful integration of foreign genes into the chloroplast genome.

\section{Phylogenetic relationships}

The phylogenies based on 61 protein-coding chloroplast genes for 33 angiosperms (Figures 3 and 4) are congruent with most relationships suggested in recent phylogenies based on complete chloroplast genome sequences (Goremykin et al., 2003, 2004, 2005; Leebens-Mack et al., 2005; Chang et al., 2006; Jansen et al., 2006; Lee S.M. et al., 2006; Ruhlman et al., 2006). There is strong support for the monophyly of many major clades of angiosperms, including monocots, eudicots, rosids, asterids, eurosids II, asterids I and asterids II. Furthermore, our phylogenies, which include two additional asterids (Coffea and Lactuca), continue to strongly support a sister relationship between the asterids and Caryophyllales.

In the previous phylogenies based on complete genome sequences, several areas of incongruence were identified, including the identification of the basal angiosperm lineage, position of the magnoliids (represented by Calycanthus) and monophyly of the eurosid I clade. These incongruences have been attributed to two phenomena: limited taxon sampling and methods of phylogenetic reconstruction (Soltis and Soltis, 2004; Soltis et al., 2004; Stefanovic et al., 2004; Goremykin et al., 2005; Leebens-Mack et al., 2005; Lockhart and Penny, 2005; Martin et al., 2005; Chang et al., 2006; Jansen etal., 2006). Our phylogenetic analyses, which include several additional genomes, are congruent with regard to the relationships in two of these areas. First, both $\mathrm{MP}$ and ML trees (Figures 3 and 4) indicate that Amborella alone is sister to the remaining angiosperms, whereas, in 
previous analyses (Leebens-Mack et al., 2005; Jansen et al., 2006), MP trees supported Amborella as the earliest diverging lineage and ML trees indicated that Amborella + Nympheales together was the most basal group. Second, in our analyses, the magnoliid Calycanthus is sister to the eudicots in both MP and ML trees (Figures 3 and 4). In previous whole-genome comparisons, Calycanthus was sister to eudicots in MP trees, but was sister to a clade that included monocots + eudicots in $\mathrm{ML}$ trees. Although both MP and ML trees agree with regard to the relationships between basal angiosperms and magnoliids, support for the relationships is not strong, especially in the ML tree (Figure 4). Additional taxon sampling of magnoliids is needed to resolve their phylogenetic position. The monophyly of the eurosid I clade continues to be controversial in phylogenies based on complete chloroplast genome sequences. MP analyses (see figure 4 in Jansen et al., 2006) support the monophyly of this group, whereas $\mathrm{ML}$ trees do not. Our phylogenies using both methods indicate that the eurosid I clade is not monophyletic (Figures 3 and 4). Sampling of additional rosid taxa and genes from complete chloroplast genomes will be needed to resolve the relationships between these groups.

Finally, our phylogenetic analyses support the placement of Coffea (Rubiaceae, Gentianales) sister to the Solanales in the euasterid I clade. The position of the Rubiaceae and Gentianales is not controversial as recent single and multigene phylogenies already strongly support their placement in the same clade as the Solanales: the euasterid I clade (reviewed in Soltis et al., 2005). However, given that euasterids I include 38 families and 35000 species, much more taxon sampling is required to assess the relationships between the major clades.

In summary, this is the first report on the complete chloroplast genome sequence from a member of the Rubiaceae. The results provide essential information for the design of plastid transformation vectors for this economically important crop. However, several more members of this family must be sequenced before optimal (100\% homologous) IGS regions are identified for use in transformation studies. Currently, any IGS region could be used to transform $C$. arabica, but not any other member of this family. One of the advantages of plastid transformation is the high level of transgene expression and foreign protein accumulation. This method has the potential to produce chloroplast-transformed coffee plants highly resistant to insect pests, such as leaf miners, nematodes and coffee berry borers. Over-expression of the caffeine-degrading enzyme $\mathrm{N}$-7-demethylase compartmentalized in plastidtransformed plants of coffee would also enable the production of naturally decaffeinated coffee.
The MP and ML tree topologies strongly support the monophyly of several major clades of angiosperms, including monocots, eudicots, rosids, asterids, eurosids II, and euasterids I and II. The trees also provide support for relationships between several major clades, including the position of Amborella as the earliest diverging angiosperm lineage, a sister relationship between monocots and a clade including magnoliids and eudicots, the position of magnoliids sister to eudicots, and a sister relationship between Caryophyllales and asterids. The only incongruence between MP and ML trees concerns the relationships amongst rosid clades, but the support of the different tree topologies is weak.

\section{Experimental procedures}

Plant material of C. arabica L. was obtained from Banana Tree Co. (Easton, PA, USA). Prior to chloroplast isolation, plants were kept in the dark for 2 days to reduce the levels of starch. Chloroplasts from leaves were isolated using the sucrose step gradient method of Palmer (1986) as modified by Jansen et al. (2005). About $10 \mathrm{~g}$ of leaf tissue was homogenized in Sandbrink isolation buffer (Sandbrink et al., 1989) using prechilled tissue blender bursts at high speed for $5 \mathrm{~s}$ to obtain sufficient quantities of chloroplast. The homogenate was filtered using four layers of cheesecloth followed by one layer of miracloth (Calbiochem, La Jolla, CA, catalogue no. 475855) without squeezing. The filtrate was transferred to prechilled centrifuge tubes and centrifuged at $1000 \mathrm{~g}$ for $15 \mathrm{~min}$ at $4^{\circ} \mathrm{C}$. The pellets were resuspended in $7 \mathrm{~mL}$ of ice-cold wash buffer and gently loaded over the step gradient consisting of $18 \mathrm{~mL}$ of $52 \%$ sucrose overlayered with $7 \mathrm{~mL}$ of $30 \%$ sucrose. The sucrose step gradient was centrifuged at $76800 \boldsymbol{g}$ for $30-60$ min at $4{ }^{\circ} \mathrm{C}$ in an SW-27 centrifuge (Beckman Coulter, CA). The chloroplast band from the 30\%-52\% interface was removed using a wide-bore pipette, diluted with 10 volumes of wash buffer and centrifuged at $1500 \boldsymbol{g}$ for $15 \mathrm{~min}$ at $4{ }^{\circ} \mathrm{C}$. Purified chloroplast pellets were resuspended in a final volume of $2 \mathrm{~mL}$. The entire chloroplast genome was amplified by rolling circular amplification (RCA) using the Repli-g RCA Kit (Qiagen GmbH, Hilden, Germany), following the methods described by Jansen et al. (2005). RCA was performed at $30^{\circ} \mathrm{C}$ for $16 \mathrm{~h}$; the reaction was terminated with a final incubation at $65^{\circ} \mathrm{C}$ for $10 \mathrm{~min}$. Digestion of the RCA product with the restriction enzymes BstXl, EcoRI and Hindlll verified successful genome amplification, as well as the DNA quality for sequencing.

\section{DNA sequencing and genome assembly}

Purified RCA products were subjected to nebulization, followed by end repair, and size fractionated by agarose gel electrophoresis to obtain fragment lengths ranging from 2.0 to $3.5 \mathrm{~kb}$. Repaired products were blunt-end cloned into $\mathrm{pCR} \mathrm{R}^{\circledR}-4 \mathrm{Blunt}-\mathrm{TOPO}$, followed by transformation into ElectroMax ${ }^{\mathrm{TM}} \mathrm{DH} 5$ alpha cells by electroporation (TOPO ${ }^{\circledR}$ Shotgun Cloning Kit; Invitrogen, Carlsbad, CA, USA). Transformed cells were selected on Luria-Bertani (LB) agar containing $100 \mu \mathrm{g} / \mu \mathrm{L}$ ampicillin and arrayed into $30 \times 96$-well microtitre 
plates. Sequencing reactions were carried out in both the forward and reverse directions using the BigDye ${ }^{\circledR}$ Terminator v3.1 Cycle Sequencing Kit and separated by a 3730xL DNA Sequence Analyser (Applied Biosystems, Foster City, CA, USA). Sequence data were assembled using SEQUeNCHER version 4.5 (GeneCodes, Ann Arbor, $\mathrm{MI}$, USA) following quality and vector trimming. Gap regions were filled by sequencing polymerase chain reaction (PCR) fragments generated from primers designed to flank the gaps. The assembly was considered to be complete when a sequence with a confidence score of 20, as judged by KB Basecaller software (Applied Biosystems), was accumulated at every base position with at least $4 \times$ coverage.

\section{Gene annotation}

Dual Organellar GenoMe Annotator (DOGMA) (Wyman et al., 2004) was used to annotate the complete coffee chloroplast genome, after uploading a FASTA-formatted file of the complete nucleotide sequence to the program's server. BLASTX and BLASTN searches, against a custom database of previously published chloroplast genomes, identified putative protein-coding genes, and tRNAs or rRNAs. For genes with low sequence identity, manual annotation was performed, after identifying the position of the start and stop codons, as well as the translated amino acid sequence, using the chloroplast/bacterial genetic code.

\section{Examination of repeat structure}

Repeats were identified for the coffee genome using CRA (N. Holtshulte and S. Wyman (Williamstown, MA), unpubl. data; http://bugmaster. jgi-psf.org/repeats/). This program filters the redundant output of REPuter (Kurtz et al., 2001) and identifies shared repeats amongst the input genomes. For repeat identification, the following constraints were set in CRA: a minimum repeat size of $30 \mathrm{bp}$ and a Hamming distance of 3 (i.e. a sequence identity of $90 \%$ or more). Manual verification of the identified repeats was obtained using the program EDITSEQ of DNA star, whilst performing an intragenomic BLAST search of the identified repeat sequences.

\section{Whole-genome sequence alignment}

MultiPipMaker (Schwartz et al., 2003; http://bio.cse.psu.edu) was used for whole-genome alignment of coffee with four published chloroplast genomes from the related family Solanaceae (Atropa bellodonna, NC_004561, Schmitz-Linneweber, 2002; Solanum bulbocastanum, NC_007943, Daniell et al., 2006; Nicotiana tabacum, NC_001879, Shinozaki et al., 1986; Solanum lycopersicum, DQ347959, Daniell et al., 2006).

\section{Phylogenetic analyses}

The 61 genes included in the analyses of Goremykin et al. (2003), Leebens-Mack et al. (2005), Jansen et al. (2006) , Lee S.B. et al. (2006) and Ruhlman et al. (2006) were extracted from the chloroplast genome sequence of Coffea using DOGMA (Wyman et al., 2004). The same set of 61 genes was extracted from the chloroplast genome sequences of 34 other sequenced chloroplast genomes (see Table 4 for a complete list of the genomes examined). All 61 protein-coding genes of the 35 taxa were translated into amino acid sequences and aligned using MUSCLE (Edgar, 2004), followed by manual adjustments; the nucleotide sequences of these genes were aligned by constraining them to the aligned amino acid sequences. A Nexus file with character sets for phylogenetic analyses was generated after nucleotide sequence alignment had been completed. The complete nucleotide alignment is available online at: http://www.biosci.utexas.edu/lB/faculty/jansen/ lab/research/data_files/index.htm.

Phylogenetic analyses using MP and ML were performed with PAUP* version 4.10 (Swofford, 2003) and GARL version 0.942 (Zwickl, 2006). Phylogenetic analyses excluded gap regions to avoid ambiguities in regions with problematic alignment, which was especially needed for the more divergent genes ccs A, matK, rpoC2, rps 15 and rps18. All MP searches included 100 random addition replicates and tree bisection-reconnection (TBR) branch swapping with the Multrees option. Modeltest 3.7 (Posada and Crandall, 1998) was used to determine the most appropriate model of DNA sequence evolution for the combined 61-gene data set. Hierarchical likelihood ratio tests and the Akaike information criterion were used to assess which of the 56 models best fitted the data, which was determined to be GTR $+I+\Gamma$ by both criteria. ML analyses were performed using GARLI version 0.93 (Zwickl, 2006). Two independent GARLI runs were performed and the ML scores for the best tree were optimized in PAUP. Non-parametric bootstrap analyses (Felsenstein, 1985) were performed in PAUP for MP analyses with 1000 replicates with TBR branch swapping, one random addition replicate and the Multrees option, and for ML analyses with 100 replicates with nearestneighbour interchange (NNI) branch swapping, one random addition replicate and the Multrees option.

\section{Acknowledgements}

The investigations reported in this article were supported in part by grants from the United States Department of Agriculture (USDA 3611-21000-017-00D) and National Institutes of Health (NIH R01 GM 63879) to Henry Daniell and the National Science Foundation (NSF DEB 0120709) to Robert K. Jansen. The authors would like to thank Jerry Mozoruk for technical assistance in sample preparation, initial genome assembly and DNA preparation.

\section{References}

Asano, T., Tsudzuki, T., Takahashi, S., Shimada, H. and Kadowaki, K. (2004) Nucleotide sequence of the sugarcane (Saccharum officinarum) chloroplast genome: a comparative analysis of four monocot chloroplast genomes. DNA Res. 11, 93-99.

Ashihara, H. and Crozier, A. (2001) Caffeine: a well known but little mentioned compound in plant science. Trends Plant Sci. 6, 407413.

Barton, C., Adam, T.L. and Zaarowitz, M.A. (1991) Stable transformation of foreign DNA into Coffea arabica plants. In: 14th International Conference on Coffee Science, San Francisco, CA, USA, pp. 460-464. Paris: ASIC (Association Scientifique Internationale du Café). 
Bausher, M.G., Singh, N.D., Lee, S.-B., Jansen, R.K. and Daniell, H. (2006) The complete chloroplast genome sequence of Citrus sinensis (L.) Osbeck var 'Ridge Pineapple': organization and phylogenetic relationships to other angiosperms. BMC Plant Biol. 6, 21.

Carneiro, M. (1997) Coffee biotechnology and its application in genetic transformation. Euphytica, 96, 167-172.

Chang, C.-C., Lin, H.-C., Lin, I.-P., Chow, T.-Y., Chen, H.-H., Chen, W.-H., Cheng, C.-H., Lin, C.-Y., Liu, S.-M., Chang, C.-C. and Chaw, S.-M. (2006) The chloroplast genome of Phalaenopsis aphrodite (Orchidaceae): comparative analysis of evolutionary rate with that of grasses and its phylogenetic implications. Mol. Biol. Evol. 23, 279-291.

Chumley, T.W., Palmer, J.D., Mower, J.P., Fourcade, H.M., Caile, P.J., Boore, J.L. and Jansen, R.K. (2006) The complete chloroplast genome sequence of Pelargonium $\times$ hortorum: organization and evolution of the largest and most highly rearranged chloroplast genome of land plants. Mol. Biol. Evol. 23, 1-16.

Chung, H.-J., Jung, J.D., Park, H.-W., Kim, J.-H., Cha, H.W., Min, S.R., Jeong, W.-J. and Liu, J.R. (2006) The complete chloroplast genome sequence of Solanum tuberosum and comparative analysis with Solanaceae species identified the presence of a 241-bp deletion in cultivated potato chloroplast DNA sequence. Plant Cell Rep. 25, 1369-1379.

Daniell, H. (2002) Molecular strategies for gene containment in transgenic crops. Nat. Biotechnol. 20, 581-586.

Daniell, H., Datta, R., Varma, S., Gray, S. and Lee, S.B. (1998) Containment of herbicide resistance through genetic engineering of the chloroplast genome. Nat. Biotechnol. 16, 345-348.

Daniell, H., Lee, S.B., Panchal, T. and Wiebe, P.O. (2001) Expression of the native cholera toxin $B$ subunit gene and assembly as functional oligomers in transgenic tobacco chloroplasts. J. Mol. Biol. 311, 1001-1009.

Daniell, H., Khan, M.S. and Allison, L. (2002) Milestones in chloroplast genetic engineering: an environmentally friendly era in biotechnology. Trends Plant Sci. 7, 84-91.

Daniell, H., Cohill, P., Kumar, S. and Dufourmantel, N. (2004a) Chloroplast genetic engineering. In: Molecular Biology and Biotechnology of Plant Organelles (Daniell, H. and Chase, C., eds), pp. 423-468. Dordrecht: Kluwer Academic Publishers.

Daniell, H., Ruiz, O. and Dhingra, A. (2004b) Chloroplast genetic engineering to improve agronomic traits. Methods Mol. Biol. 286, 111-138

Daniell, H., Kumar, S. and Dufourmantel, N. (2005) Breakthrough in chloroplast genetic engineering of agronomically important crops. Trends Biotechnol. 23, 238-245.

Daniell, H., Lee, S.B., Grevich, J., Saski, C., Guda, C., Tomkins, J. and Jansen, R.K. (2006) Complete chloroplast genome sequences of Solanum bulbocastanum, Solanum lycopersicum and comparative analyses with other Solanaceae genomes. Theor. Appl. Genet. 112, 1503-1518.

DeCosa, B., Moar, W., Lee, S.B., Miller, M. and Daniell, H. (2001) Overexpression of the $B t$ Cry2Aa2 operon in chloroplasts leads to formation of insecticidal crystals. Nat. Biotechnol. 19, 71-74.

DeGray, G., Rajasekaran, K., Smith, F., Sanford, J. and Daniell, H. (2001) Expression of an antimicrobial peptide via the chloroplast genome to control phytopathogenic bacteria and fungi. Plant Physiol. 127, 852-862.

Dufourmantel, N., Pelissier, B., Garcon, F., Peltier, G., Ferullo, J.M. and Tissot, G. (2004) Generation of fertile transplastomic soybean. Plant Mol. Biol. 55, 479-489.
Dufourmantel, N., Tissot, G., Goutorbe, F., Garcon, F., Muhr, C., Jansens, S., Pelissier, B., Peltier, G. and Dubald, M. (2005) Generation and analysis of soybean plastid transformants expressing Bacillus thuringiensis Cry1 Ab protoxin. Plant Mol. Biol. 58, 659-658.

Edgar, R.C. (2004) MUSCLE: a multiple sequence alignment method with reduced time and space complexity. BMC Bioinformatics, 5, 113.

Felsenstein, J. (1985) Confidence limits on phylogenies: an approach using the bootstrap. Evolution, 39, 783-791.

Goremykin, V.V., Hirsch-Ernst, K.I., Wolfl, S. and Hellwig, F.H. (2003) Analysis of the Amborella trichopoda chloroplast genome sequence suggests that Amborella is not a basal angiosperm. Mol. Biol. Evol. 20, 1499-1505.

Goremykin, V.V., Hirsch-Ernst, K.I., Wolfl, S. and Hellwig, F.H. (2004) The chloroplast genome of Nymphaea alba: wholegenome analyses and the problem of identifying the most basal angiosperm. Mol. Biol. Evol. 21, 1445-1454.

Goremykin, V.V., Holland, B., Hirsch-Ernst, K.I. and Hellwig, F.H. (2005) Analysis of Acorus calamus chloroplast genome and its phylogenetic implications. Mol. Biol. Evol. 22, 1813-1822.

Grevich, J.J. and Daniell, H. (2005) Chloroplast genetic engineering: recent advances and future perspectives. Crit. Rev. Plant Sci. 24, 83-107.

Hiratsuka, J., Shimada, H., Whittier, R., Ishibashi, T., Sakamoto, M., Mori, M., Kondo, C., Honji, Y., Sun, C.R., Meng, B.Y., Li, Y.Q., Kanno, A., Nishizawa, Y., Hirai, A., Shinozaki, K. and Sugiura, M. (1989) The complete sequence of the rice (Oryza sativa) chloroplast genome: intermolecular recombination between distinct tRNA genes accounts for a major plastid DNA inversion during the evolution of the cereals. Mol. Gen. Genet. 217, 185-194.

Hupfer, H., Swaitek, M., Hornung, S., Herrmann, R.G., Maier, R.M., Chiu, W.L. and Sears, B. (2000) Complete nucleotide sequence of the Oenothera elata plastid chromosome, representing plastome 1 of the five distinguishable Euoenthera plastomes. Mol. Gen. Genet. 263, 581-585.

Jansen, R.K., Boore, J.L., dePamphilis, C.W., Chumley, T.W., Haberle, R.C., Wyman, S.K., Alverson, A.J., Peery, R., Herman, S.J., Fourcade, H.M., Kuehl, J.V., McNeal, J.R., Leebens-Mack, J. and Cui, L. (2005) Methods for obtaining and analyzing whole chloroplast genome sequences. Methods Enzymol. 395, 348-384.

Jansen, R.K., Kaittanis, C., Saski, C., Lee, S.B., Tomkins, J., Alverson, A.J. and Daniell, H. (2006) Phylogenetic analyses of Vitis (Vitaceae) based on complete chloroplast genome sequences: effects of taxon sampling and phylogenetic methods on resolving relationships among rosids. BMC Evol. Biol. 6, 32.

Kanamoto, H., Yamashita, A., Asao, H., Okumura, S., Takase, H., Hattori, M., Akiho Yokota, A. and Tomizawa, K. (2006) Efficient and stable transformation of Lactuca sativa L. cv. Cisco (lettuce) plastids. Transgenic Res. 15, 205-217.

Kato, T., Kaneko, T., Sato, S., Nakamura, Y. and Tabata, S. (2000) Complete structure of the chloroplast genome of a legume, Lotus japonicus. DNA Res. 7, 323-330.

Kim, K.J. and Lee, H.L. (2004) Complete chloroplast genome sequences from Korean ginseng (Panax schinseng Nees) and comparative analysis of sequence evolution among 17 vascular plants. DNA Res. 11, 247-261.

Kota, M., Daniell, H., Varma, S., Garczynski, S.F., Gould, F. and Moar, W.J. (1999) Overexpression of the Bacillus thuringiensis (Bt) Cry2Aa2 protein in chloroplasts confers resistance to plants against susceptible and Bt-resistant insects. Proc. Natl Acad. Sci. USA 96, 1840-1845. 
Kumar, S., Dhingra, A. and Daniell, H. (2004a) Chloroplastexpressed betaine aldehyde dehydrogenase gene in carrot cultured cells, roots, and leaves confers enhanced salt tolerance. Plant Physiol. 136, 2843-2854.

Kumar, S., Dhingra, A. and Daniell, H. (2004b) Stable transformation of the cotton chloroplast genome and maternal inheritance of transgenes. Plant Mol. Biol. 56, 203-216.

Kurtz, S., Choudhuri, J.V., Ohlebusch, E., Schleiermacher, C., Stoye, J. and Giegerich, R. (2001) REPuter: the manifold applications of repeat analysis on a genomic scale. Nucleic Acids Res. 29, 46334642.

Lee, S.-B., Kwon, H., Kwon, S., Park, S., Jeong, M., Han, S. and Daniell, H. (2003) Accumulation of trehalose within transgenic chloroplast confers drought tolerance. Mol. Breed. 11, 1-13.

Lee, S.-B., Kaittanis, C., Jansen, R.K., Hostetler, J.B., Tallon, L.J., Town, C.D. and Daniell, H. (2006) The complete chloroplast genome sequence of Gossypium hirsutum: organization and phylogenetic relationships to other angiosperms. BMC Genomics, 7, 61 .

Lee, S.M., Kang, K., Chung, H., Yoo, S.J., Xu, X.M., Lee, S.-B., Cheong, J.J., Daniell, H. and Kim, M. (2006) Plastid transformation in the monocotyledonous cereal crop, rice (Oryza sativa), and transmission of transgenes to their progeny. Mol. Cells, 21, 401410.

Leebens-Mack, J., Raubeson, L.A., Cui, L., Kuehl, J., Fourcade, M., Chumley, T., Boore, J.L., Jansen, R.K. and dePamphilis, C.W. (2005) Identifying the basal angiosperms in chloroplast genome phylogenies: sampling one's way out of the Felsenstein zone. Mol. Biol. Evol. 22, 1948-1963.

Leelavathi, S., Naveen Gupta, N., Maiti, S., Ghosh, A. and Reddy, V.S. (2003) Overproduction of an alkali- and thermostable xylanase in tobacco chloroplasts and efficient recovery of the enzyme. Mol. Breed. 11, 59-67.

Lelivelt, C., McCabe, M., Newell, C., deSnoo, C., Dun, K., BirchMachin, I., Gray, J., Mills, K. and Nugent, J. (2005) Stable plastid transformation in lettuce (Lactuca sativa L.). Plant Mol. Biol. 58, $763-774$.

Leroy, T., Henry, A.-M., Royer, M., Altosaar, I., Frutos, R., Duris, D. and Philippe, R. (2000) Genetically modified coffee plants expressing the Bacillus thuringiensis cry1Ac gene for resistance to leaf miner. Plant Cell Rep. 19, 382-389.

Lockhart, P.J. and Penny, D. (2005) The place of Amborella within the radiation of angiosperms. Trends Plant Sci. 10, 201-202.

Maier, R.M. and Schmitz-Linneweber (2004) Chloroplast genomes. In: Molecular Biology and Biotechnology of Plant Organelles (Daniell, H. and Chase, C., eds), pp. 115-150. The Netherlands: Springer.

Maier, R.M., Neckermann, K., Igloi, G.L. and Kossel, H. (1995) Complete sequence of the maize chloroplast genome: gene content, hotspots of divergence and fine tuning of genetic information by transcript editing. J. Mol. Biol. 251, 614-628.

Martin, W., Deusch, O., Stawski, N., Grunheit, N. and Goremykin, V. (2005) Chloroplast genome phylogenetics: why we need independent approaches to plant molecular evolution. Trends Plant Sci. 10, 203-209.

Mendez-Lopez, I., Basurto-Rios, R. and Ibarra, J.E. (2003) Bacillus thuringiensis serovar israelensis is highly toxic to the coffee berry borer, Hypothenemus hampei Ferr. (Coleoptera: Scolytidae). FEMS Microbiol. Lett. 226, 73-77.

Millen, R.S., Olmstead, R.G., Adams, K.L., Palmer, J.D., Lao, N.T.,
Heggie, L., Kavanagh, T.A., Hibberd, J.M., Gray, J.C., Morden, C.W., Calie, P.J., Jermiin, L.S. and Wolfe, K.H. (2001) Many parallel losses of infA from chloroplast DNA during angiosperm evolution with multiple independent transfers to the nucleus. Plant Cell, 13, 645-658.

Ocampo, C. and Manzanera, L.M. (1991) Advances in genetic manipulation of coffee plant. In: 14th International Conference on Coffee Science, San Francisco, CA, USA, pp. 73-81. Paris: ASIC (Association Scientifique Internationale du Café).

Ogihara, Y., Isono, K., Kojima, T., Endo, A., Hanaoka, M., Shiina, T., Terachi, T., Utsugi, S., Murata, M., Mori, N., Takumi, S., Ikeo, K., Gojobori, T., Murai, R., Murai, K., Matsuoka, Y., Ohnishi, Y., Tajiri, H. and Tsunewaki, K. (2002) Structural features of a wheat plastome as revealed by complete sequencing of chloroplast DNA. Mol. Gen. Genet. 266, 740-746.

Ogita, S., Uefuji, H., Yamaguchi, Y., Koizumi, N. and Sano, H. (2003) RNA interference producing decaffeinated coffee plants. Nature, 423, 823.

Okumura, S., Sawada, M., Park, Y.W., Hayashi, T., Shimamura, M., Takase, H. and Tomizawa, K. (2006) Transformation of poplar (Populus alba) plastids and expression of foreign proteins in tree chloroplasts. Transgenic Res. 15, 637-646.

Palmer, J.D. (1986) Isolation and structural analysis of chloroplast DNA. Meth. Enzymol. 118, 167-186.

Penna, S., Saggi, L. and Swennen, R. (2002) Positive selectable marker genes for routine plant transformation. In Vitro Cell Dev. Biol. Plant. 38, 125-128.

Pereira, L.F.P., Galvão, R.M., Kobayash, A.K., Cação, S.M.B. and Vieira, L.G.E. (2005) Ethylene production and acc oxidase gene expression during fruit ripening of Coffea arabica L. Braz. J. Plant Physiol. 17, 283-289.

Pombert, J.-F., Otis, C., Lemieux, C. and Turmel M. (2005) The chloroplast genome sequence of the green alga Pseudendoclonium akinetum Ulvophyceae reveals unusual structural features and new insights into the branching order of chlorophyte lineages. Mol. Biol. Evol. 22, 1903-1918.

Pombert, J.-F., Lemieux, C. and Turmel, M. (2006) The complete chloroplast DNA sequence of the green alga Oltmannsiellopsis viridis reveals a distinctive quadripartite architecture in the chloroplast genome of early diverging ulvophytes. BMC Biol. 4, 3.

Posada, D. and Crandall, K.A. (1998) MoDELTEST: testing the model of DNA substitution. Bioinformatics, 14, 817-818.

Quesada-Vargas, T., Ruiz, O.N. and Daniell, H. (2005) Characterization of heterologous multigene operons in transgenic chloroplasts: transcription, processing, and translation. Plant Physiol. 138, 1746-1762.

Raubeson, L.A. and Jansen, R.K. (2005) Chloroplast genomes of plants. In: Diversity and Evolution of Plants - Genotypic and Phenotypic Variation in Higher Plants (Henry, R.J., ed.), pp. 4568. Wallingford: CABI Publishing.

Ribas, A.F., Pereira, I.I.F.P. and Vieira, L.G.E. (2006) Genetic transformation of coffee. Braz. J. Plant Physiol. 18, 83-94.

Ruf, S., Hermann, M., Berger, I.J., Carrer, H. and Bock, R. (2001) Stable genetic transformation of tomato plastids and expression of a foreign protein in fruit. Nat. Biotechnol. 19, 870-875.

Ruhlman, T., Lee, S.B., Jansen, R.K., Hostetler, J.B., Tallon, L.J., Town, C.D. and Daniell, H. (2006) Complete plastid genome sequence of Daucus carota: implications for biotechnology and phylogeny of angiosperms. BMC Genomics, 7, 224. 
Ruiz, O.N. and Daniell, H. (2005) Engineering cytoplasmic male sterility via the chloroplast genome by expression of betaketothiolase. Plant Physiol. 138, 1232-1246.

Ruiz, O.N., Hussein, H.S., Terry, N. and Daniell, H. (2003) Phytoremediation of organomercurial compounds via chloroplast genetic engineering. Plant Physiol. 132, 1344-1352.

Sandbrink, J.M., Vellekoop, P., Vanham, R. and Vanbrederode, J. (1989) A method for evolutionary studies on RFLP of chloroplast DNA, applicable to a range of plant species. Biochem. Syst. Ecol. 17, 45-49.

Saski, C., Lee, S.-B., Daniell, H., Wood, T., Tomkins, J., Kim, H.-G. and Jansen, R. (2005) Complete chloroplast genome sequence of Glycine max and comparative analyses with other legume genomes. Plant Mol. Biol. 59, 309-322.

Sato, S., Nakamura, Y., Kaneko, T., Asamizu, E. and Tabata, S. (1999) Complete structure of the chloroplast genome of Arabidopsis thaliana. DNA Res. 6, 283-290.

Schmitz-Linneweber, C., Maier, R.M., Alcaraz, J.P., Cottet, A., Herrmann, R.G. and Mache, R. (2001) The plastid chromosome of spinach (Spinacia oleracea): complete nucleotide sequence and gene organization. Plant Mol. Biol. 45, 307-315.

Schmitz-Linneweber, C., Du Regel, R.T.G., Hupfer, H., Herrmann, R.G. and Maier, R.M. (2002) The plastid chromosome of Atropa belladonna and its comparison with that of Nicotiana tabacum: the role of RNA editing in generating divergence in the process of plant speciation. Mol. Biol. Evol. 19, 1602-1612.

Schwartz, S., Elnitski, L., Li, M., Weirauch, M., Riemer, C., Smit, A., Green, E.D., Hardison, R.C. and Webb M. (2003) MultiPipMaker and supporting tools: alignments and analysis of multiple genomic DNA sequences. Nucleic Acids Res. 31, 3518-3524.

Scott, S.E. and Wilkinson, M.J. (1999) Low probability of chloroplast movement from oilseed rape (Brassica napus) into wild Brassica rapa. Nat. Biotechnol. 17, 390-392.

Shinozaki, K., Ohme, M., Tanaka, M., Wakasugi, T., Hayashida, N., Matsubayashi, T., Zaita, N., Chunwongse, J., Obokata, J., Yamaguchi-Shinozaki, K., Ohto, C., Torazawa, K., Meng, B.Y., Sugita, M., Deno, H., Kamogashira, T., Yamada, K., Kusuda, J., Takaiwa, F., Kato, A., Tohdoh, N., Shimada, H. and Sugiura, M. (1986) The complete nucleotide sequence of the tobacco chloroplast genome: its gene organization and expression. EMBO J. $\mathbf{5}$, 2043-2049.

Sidorov, V.A., Kasten, D., Pang, S.-Z., Hajdukiewicz, P.T.J.M., Staub, J.M. and Nehra, N.S. (1999) Stable chloroplast transformation in potato: use of green fluorescent protein as a plastid marker. Plant J. 19, 209-216.

Soltis, D.E. and Soltis, P.S. (2004) Amborella not a 'basal angiosperm'? Not so fast. Am. J. Bot. 91, 997-1001.
Soltis, D.E., Albert, V.A., Savolainen, V., Hilu, K., Qiu, Y.L., Chase, M.W., Farris, J.S., Stefanovic, S., Rice, D.W., Palmer, J.D. and Soltis, P.S. (2004) Genome-scale data, angiosperm relationships, and 'ending incongruence': a cautionary tale in phylogenetics. Trends Plant Sci. 9, 477-483.

Soltis, D.E., Soltis, P.S., Endress, P.K. and Chase, M.W. (2005) Phylogeny and Evolution of Angiosperms. Sunderland, MA: Sinauer Associates Inc.

Spiral, J. and Pétiard, V. (1991) Protoplast culture and regeneration in Coffea species. In: 14th International Conference on Coffee Science, San Francisco, CA, USA, pp. 383-391. Paris: ASIC (Association Scientifique Internationale du Café).

Steane, D.A. (2005) Complete nucleotide sequence of the chloroplast genome from the Tasmanian blue gum, Eucalyptus globulus (Myrtaceae). DNA Res. 12, 215-220.

Stefanovic, S., Rice, D.W. and Palmer, J.D. (2004) Long branch attraction, taxon sampling, and the earliest angiosperms: Amborella or monocots? BMC Evol. Biol. 4, 35.

Stevens, P.F. (2006) Angiosperm Phylogeny Website, Version 7. URL http://www.mobot.org/MOBOT/research/APweb/ [accessed on 27 December 2006].

Swofford, D.L. (2003) PAUP*: Phylogenetic Analysis Using Parsimony (*and Other Methods), Version 4.0. Sunderland MA: Sinauer Associates.

Timme, R.E., Kuehl, J.V., Boore, J.L. and Jansen, R.K. (2007) A comparative analysis of the Lactuca and Helianthus (Asteraceae) plastid genomes: identification of divergent regions and categorization of shared repeats. Am. J. Bot., in press.

USDA (2005) Tropical Products: World Markets and Trade. Washington, DC: USDA, Foreign Agriculture Service.

Van Boxtel, J., Berthouly, M., Carasco, C., Dufour, M. and Eskes, A. (1995) Transient expression of $\beta$-glucuronidase following biolistic delivery of foreign DNA into coffee tissues. Plant Cell Rep. 14, 748-752.

Van Boxtel, J., Eskes, A. and Berthouly, M. (1997) Glufosinate as an efficient inhibitor of callus proliferation in coffee tissue. In Vitro Cell. Dev. Biol. Plant. 33, 6-12.

Wakasugi, T., Tsudzuki, J., Ito, S., Nakashima, K., Tsudzuki, T. and Sugiura, M. (1994) Loss of all ndh genes as determined by sequencing the entire chloroplast genome of the black pine Pinus thunbergii. Proc. Natl Acad. Sci. USA 91, 9794-9798.

Wyman, S.K., Jansen, R.K. and Boore, J.L. (2004) Automatic annotation of organellar genomes with DOGMA. Bioinformatics, 20, 3252-3255.

Zwickl, D.J. (2006) GARLI (Genetic Algorithm for Rapid Likelihood Inference), Version 0.942. URL http://www.bio.utexas.edu/grad/ zwickl/web/garli.html [accessed on 4 July 2006]. 